Original research article

\title{
Early rehabilitation after stroke in comprehensive cerebrovascular centres in the Czech Republic: a comparison of three stroke units
}

\author{
Anna Kratochvílová ${ }^{1}$, Vladimír Rogalewicz ${ }^{2}$, Yvona Angerová ${ }^{2}$, Tereza Gueye ${ }^{2,3}$, Pavel Maršálek ${ }^{4}$, \\ Irina Chmelová ${ }^{5,6}$, Miroslav Barták ${ }^{7 *}$ \\ ${ }^{1}$ Czech Technical University in Prague, CzechHTA, Faculty of Biomedical Engineering, Department of Biomedical Technology, Kladno, Czech Republic \\ ${ }^{2}$ Charles University and General University Hospital in Prague, First Faculty of Medicine, Department of Rehabilitation Medicine, Prague, \\ Czech Republic \\ ${ }^{3}$ University Hospital Královské Vinohrady, Department of Rehabilitation Medicine, Prague, Czech Republic \\ ${ }^{4}$ Krajská zdravotní, a. s., Masaryk Hospital in Ústí nad Labem, Rehabilitation Department, Ústí nad Labem, Czech Republic \\ ${ }^{5}$ University Hospital Ostrava, Clinic of Rehabilitation and Physical Medicine, Ostrava, Czech Republic \\ ${ }^{6}$ University of Ostrava, Faculty of Medicine, Department of Rehabilitation, Ostrava, Czech Republic \\ ${ }^{7}$ University of South Bohemia in České Budějovice, Faculty of Health and Social Sciences, Institute of Social and Special-paedagogical Sciences, \\ České Budějovice, Czech Republic
}

\section{Abstract}

Quality of life and costs related to stroke survivors are important issues for the Czech healthcare system. Early rehabilitation after stroke has a great potential to improve patients' quality of life as well as to contribute to saving long-term societal costs. A tri-centre pragmatic longitudinal study was focused on the economic analysis of early rehabilitation after stroke in hospitals in the Czech Republic. The research also revealed dissimilarities in procedures between the involved hospitals. The number of patients included in the study was 87 (Prague 29, Ústí nad Labem - 31, Ostrava - 27). All of them were admitted to the early rehabilitation unit less than 70 days after stroke. Data were collected using the bottom-up method alongside the standard patient care. The inter-hospital differences manifested themselves mainly in the severity of the patients transferred from neurology to early rehabilitation wards, length of the hospitalization, average cost of the hospital stay, and to some degree also in the clinical outcomes (represented by the FIM scores). The analysis showed improvements in clinical outcomes in all groups and all hospitals. The differences in the costs of the hospitalization were caused predominantly by hospitalization length. The differences in the average one-day costs were caused only by particular hospitals' treatment procedures and operational processes.
\end{abstract}

Keywords: Czech Republic; Early rehabilitation; Inter-hospital differences; Stroke

\section{Introduction}

It is estimated that the number of people living with a stroke will increase by $27 \%$ between 2017 and 2047 in the European Union, mainly because of population ageing and improved survival rates (Wafa et al., 2020). This also holds true for the Czech Republic. The incidence estimate according to the Global Burden of Disease study is about 18,445 strokes per year, i.e. 106.8 strokes per 100,000 inhabitants annually, age- and sex-adjusted, while the prevalence estimate is 96,833 strokes, i.e. 597.9 per 100,000 inhabitants, age- and sex-adjusted (Reddy, 2016). The annual stroke costs are estimated as EUR 365.8 million in the Czech Republic (Stevens et al., 2020; Wilkins et al., 2017). Thus, early rehabilitation after stroke has been recently introduced in the Czech Republic in order to improve the quality of life of stroke survivors. It also has the potential to reduce the economic burden related to stroke induced disability. However, there was a lack of available information about its costs in the $C$ zech environment. To bridge this gap, a pragmatic study was executed in 2017 to estimate the costs of early rehabilitation after stroke in Czech hospitals.

There is a bulk of evidence that early rehabilitation is beneficial for patients after stroke (Bernhardt et al., 2015; Hamann et al., 2016; Langhorne et al., 2017; Powers et al., 2018). High-intensity rehabilitation therapy within the first 90 days is reported to be associated with a lower mortality risk than low-intensity therapy among patients with mild to moderate stroke severity (Hsieh et al., 2018). The necessity of personalized rehabilitation care for patients after stroke was also stressed by Enderby and her colleagues (Enderby et al., 2017). The last ten years of stroke treatment has been characterized

\footnotetext{
* Corresponding author: Miroslav Barták, University of South Bohemia in České Budějovice, Faculty of Health and Social Sciences, Institute of Social and Special-paedagogical Sciences, J. Boreckého 1167/27, 37011 České Budějovice, Czech Republic; e-mail: mbartak00@zsf.jcu.cz; http://doi.org/10.32725/kont.2021.013
}

Submitted: 2020-12-13 • Accepted: 2021-04-08 • Prepublished online: 2021-04-09 
by establishing specialized comprehensive stroke centres (Hamann et al., 2016; Powers et al., 2018; Škoda et al., 2016). In the Czech Republic, such stroke centres were established by the Ministry of Health in 2015 (Ministry of Health of the Czech Republic, 2015).

In the Czech Republic, there are 13 Centres of Highly Specialized Cerebrovascular Care, formerly Comprehensive Cerebrovascular Centres (consisting of neurosurgical, radiological, neurological, intensive care neurological and early rehabilitation units) and 32 Centres with Highly Specialized Care of Patients after Strokes, formerly Stroke Centres (consisting of neurological and early rehabilitation units). Typically, between the 7th and 14th day after the onset of a stroke, patients are transferred to an early rehabilitation unit, where a multiprofessional team (incl. physicians, physiotherapists, occupational therapists, speech therapists, psychologists, nutrition therapists, social workers) provide them with 3-4 hours of multiprofessional rehabilitation per day.

The objective of this study was to calculate hospitalization costs in patients after stroke during the early rehabilitation therapy at stroke units. The main economic results have been recently published (Angerova et al., 2020; 2021). The study was carried out in three backbone Czech hospitals in Prague, Ústí nad Labem and Ostrava.

\section{Materials and methods}

\section{Study design}

The national multicentric pragmatic study was carried out in three hospitals (General University Hospital in Prague, Clinic of Rehabilitation Medicine (VFN); Masaryk Hospital in Ústí nad Labem, Rehabilitation Department (MNUL); and University Hospital Ostrava, Clinic of Rehabilitation and Physical Medicine (FNO) from April until November 2017. The study was approved by the Ethics Committee of the General University Hospital in Prague on 15th December 2016. The detailed design of the study was published together with its first results (Angerova et al., 2020; 2021). The study had a pragmatic design and the individual hospitals followed their standard clinical management procedures and processes.

\section{Participants}

The data of 94 patients were collected by the convenience sampling method in VFN (30 patients), MNUL (34 patients), and FNO (30 patients). The criteria for patient inclusion were stroke diagnosed from April to September 2017 (both ischemic or haemorrhagic, primary or secondary as a complication of another therapy). Transitory cases were not included. Patients with a hospitalization of less than four days were excluded regardless of the reason. The upper limit for the hospitalization length was set to 90 days; monitoring of a patient was finished after this limit had been reached, and the reason was recorded in the patient documentation. Each patient was included only once - with the exception of an interruption of early rehabilitation due to complications treated in the same hospital. Subsequently, seven patients were excluded from the analyses, because in their case the rehabilitation started more than three months after stroke. The final number of patients included in the study was 87 , all of them were admitted to the early rehabilitation unit less than 70 days after stroke.

\section{Economic analysis}

Source data for cost calculation were collected using the bottom-up (micro-costing) method alongside the standard pa- tient care. The staff recorded pieces, volumes or time spent continuously in ten working forms. These working forms were transferred to economic forms (each working form was accompanied by an economic form) multiplying the amounts by their unit prices. All cost data are given in Czech crowns (CZK). They can be converted to EUR using the 2017 Czech National Bank average exchange rate EUR 1 = CZK 26.330.

\section{Clinical outcome analysis}

Along with working and economic forms, there were also eight clinical forms. The basic and social form was used for recording basic personal data of each patient. The physicians' form contained dates (stroke onset, hospitalization, transfer to early rehabilitation unit, and discharge from hospital) and physician's independent evaluation of the patient's functional abilities including determination of the patient's category (see below). Most clinical forms served to record the results of functional tests (the Barthel Index (BI), Extended Barthel Index (EBI), and the Functional Independence Measure (FIM), among others) carried out by trained therapists during the hospitalization; these were executed on the 3rd day of the hospitalization at the rehabilitation unit, and then every two weeks (i.e. the $3 \mathrm{rd}, 14 \mathrm{th}, 28 \mathrm{th}, 42 \mathrm{nd}, 56 \mathrm{th}, .$. day) until the discharge. Simultaneously, the patient category according to the Czech reimbursement scheme (Section 6 of [35]) was recorded. The categories are as follows: (1) patient self-sufficient, (2) patient partly self-sufficient, (3) patient requiring enhanced level of supervision, (4) patient immobile, (5) patient unconscious.

\section{Results}

From the point of view of patient categories, the most serious condition of patients was observed in VFN with the average category of 3.4, when there were no first category patients. Meanwhile, patients were in a rather fair condition in MNUL with the average category of 2.0, the same as the median. There were no fourth category patients there. The average patient category in FNO amounted to 2.3. Numbers of patients in individual categories in each hospital are shown in Chart 1.

The hospitalization was longest in VFN and shortest in FNO. The average time spent in the early rehabilitation ward was 29.5 days (95\%CI 26.0-33.0) in VFN, 21.2 days (95\%CI 16.8-25.7) in MNUL, and 15.4 days (95\%CI 13.7-17.0) in FNO. Chart 2 shows the exact numbers of patients in individual categories.

The study proved (Angerova et al., 2020) that the scores of the Barthel Index and the motor part of FIM are dependent on the categories, which is not true for the Extended Barthel Index or cognitive part of FIM. Generally, the measures based on motor skills are much more sensitive, while the cognitive results only had a small effect on the final state of patients. Both tools provided similar information; as FIM is more detailed, we use FIM for the comparison of individual hospitals (Charts 3, 4 and 5).

The initial values clearly decrease with growing categories, and these differences stay in place until the end of the hospitalization. The increase in both FIM scores and their motor parts during the hospitalization was largest in VFN, while it was lower in MNUL and FNO. It was highest in category-2 patients, when category-1 patients' relatively high initial scores did not allow similarly large improvements. Meanwhile, category-4 patients generally showed a smaller shift in scores. 


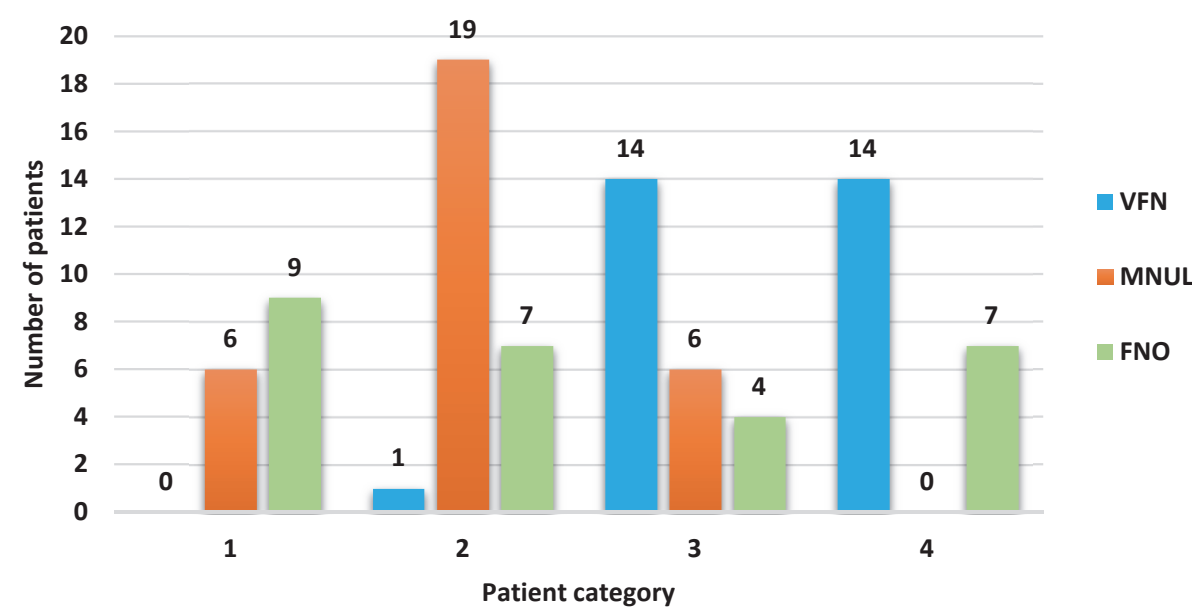

Chart 1. Comparison of hospitals according to patient categories

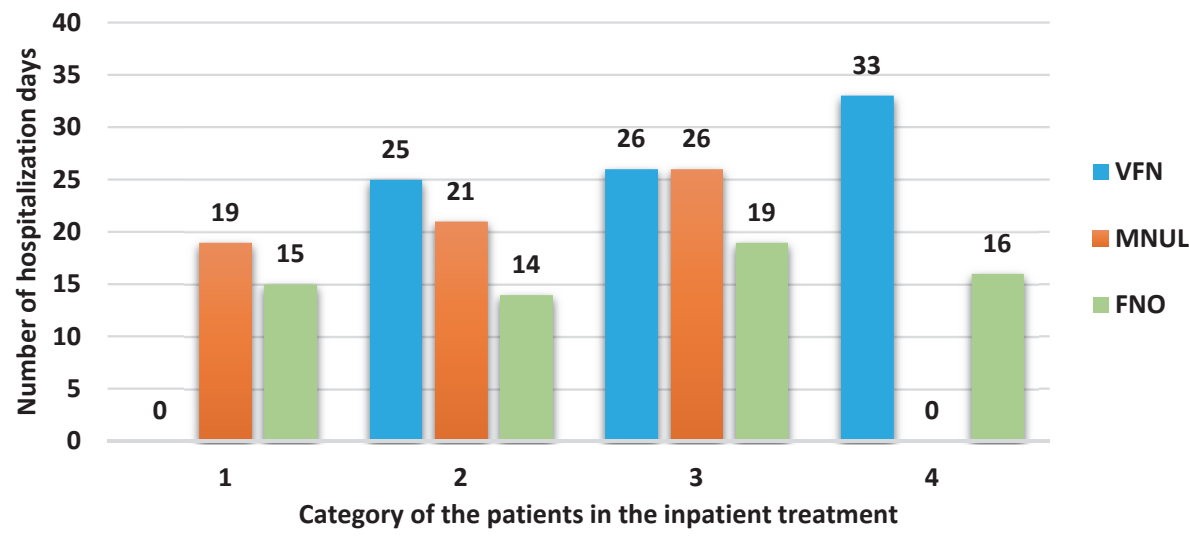

Chart 2. Comparison of hospitals according to the average length of hospitalization
VFN
MNUL
FNO

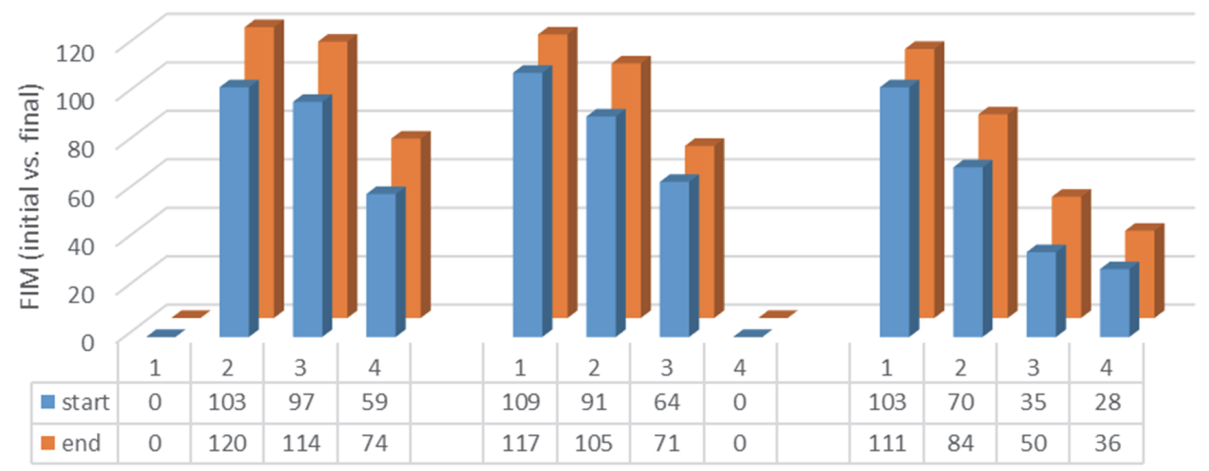

Hospitals and patient categories

Chart 3. Differences in initial and final FIM values for individual hospitals and patient categories 


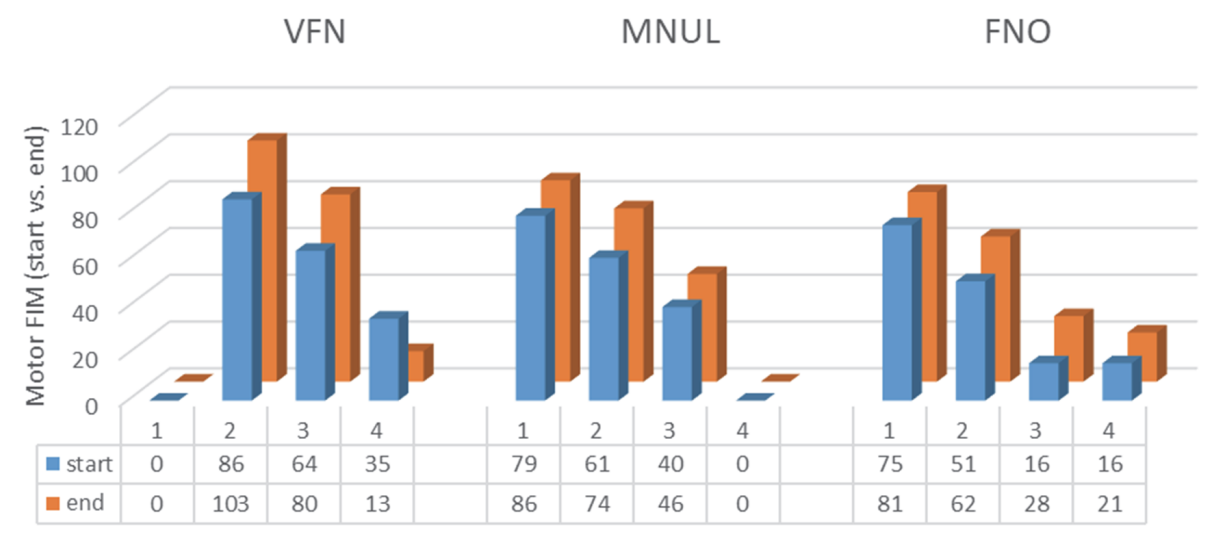

Hospitals and patient categories

Chart 4. Differences in initial and final values of FIM motor part for individual hospitals and patient categories

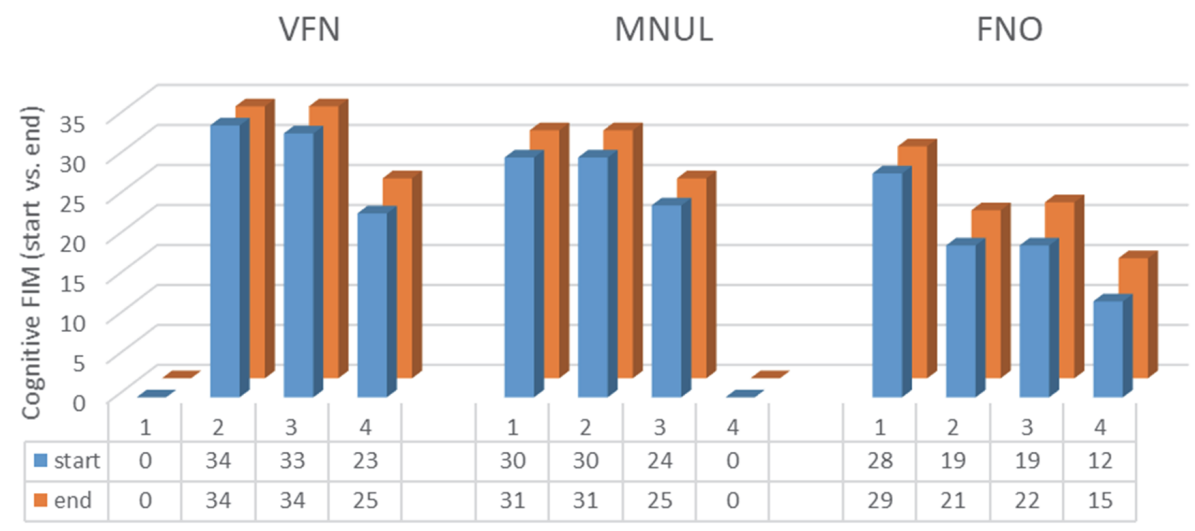

Hospitals and patient categories

Chart 5. Differences in initial and final values of FIM cognitive part for individual hospitals and patient categories

Finally, we compared the costs of early rehabilitation care in individual hospitals and monitored significant differences in costs of the care between the hospitals. While the average total costs per patient (Chart 6) differ due to the differences in the hospitalization length (see Chart 2), the differences in average one-day costs per patient (Chart 7) are caused only by the particular hospital's treatment standards and operational processes.

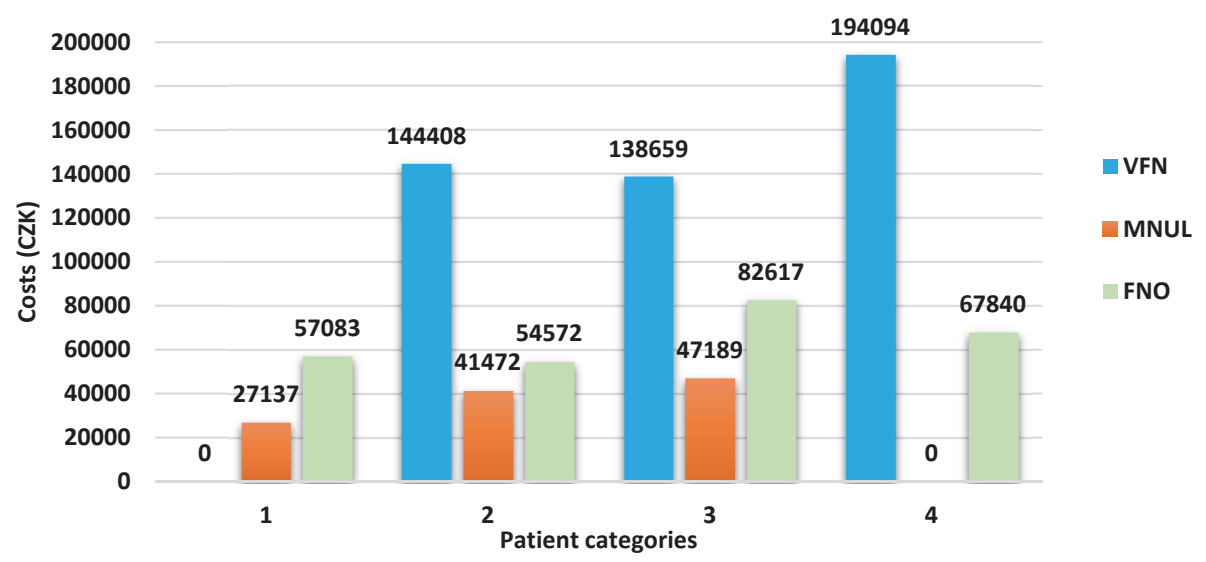

Chart 6. Average costs per hospitalization of one patient according to patient categories and hospitals 


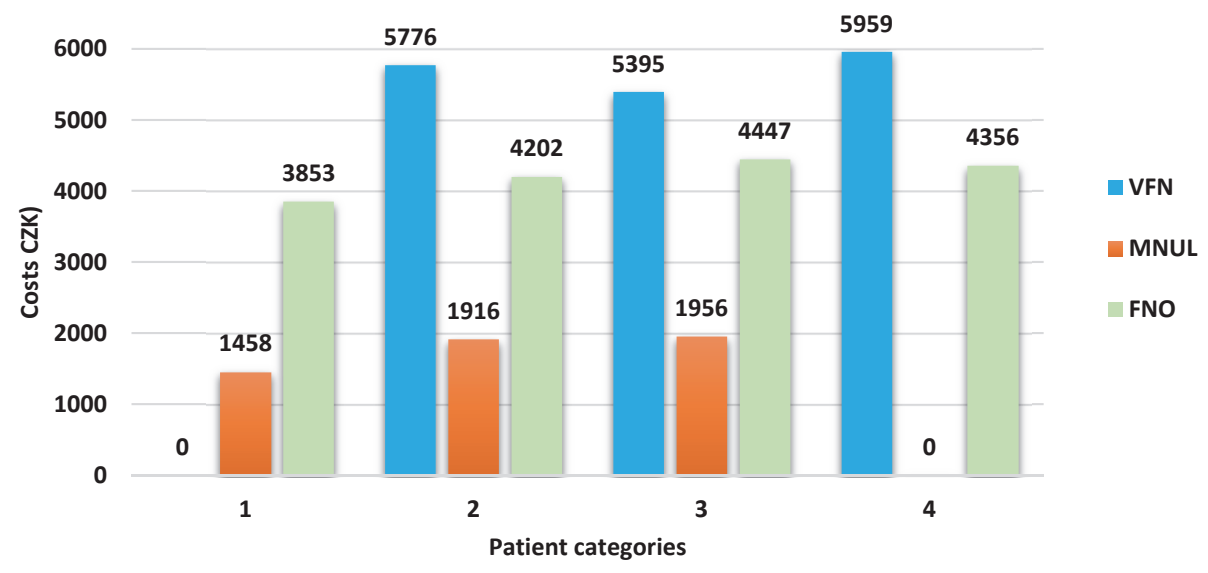

Chart 7. Average costs per one-day hospitalization of one patient according to patient categories and hospitals

\section{Discussion}

A tri-centre study focused on an economic analysis of early rehabilitation after stroke was carried out in the General University Hospital in Prague, Masaryk Hospital in Ústí nad Labem and University Hospital Ostrava. As a pragmatic observational study, the research also revealed dissimilarities in procedures between the involved hospitals. Above all, these differences manifested themselves in the severity of the condition of patients transferred from neurology to early rehabilitation wards, length of the hospitalization, average costs of the hospital stay, and to some degree the clinical outcomes (represented in this paper by the FIM scores).

Based on the legislation, there are two different types of stroke units in the Czech Republic: Centres of Highly Specialized Cerebrovascular Care, formerly Comprehensive Cerebrovascular Centres (which are a little bit higher because of the possibility of a neurosurgery program), and Centres Highly Specialized for Patients with Strokes. MNUL and FNO are the higher centres (comprehensive), while VFN is of the second type. This can contribute to the differences we found between the hospitals, and needs to be taken into consideration when assessing the costs of early rehabilitation after stroke from the perspective of healthcare payers.

The categorisation of patients poses a possible problem. While the rules for each category are prescribed by legislation, the practical implementation is influenced by local specificities. This can be seen from FIM scores assigned to patients of particular categories in individual hospitals. For example, the third category - incorporating patients who need extensive support and who are not capable of any individual movement even with a technical aid - have the average FIM scores of 97-114 in VFN, 64-71 in MNUL, and 35-50 in FNO. Although we found no significant correlation between the FIM scores and the category, the differences are quite large. Even if the staff were trained by the same specialists, the individual attitudes might vary. In contrast with the experience that the level of cognitive functions has an impact on the overall functional state of the patient (Branco et al., 2019), we found no statistically significant results in our sample in terms of the impact of daily improvement in FIM $C$ to improvements in FIM M, or in terms of the impact of the initial or final values of FIM $C$ to daily improvement in FIM M.

Finally, the differences between the results in all three hospitals may also be caused by limited homogeneity of patients (both within individual categories and between them). Studies of the predictive power of self-sufficiency tests have often focused on very narrowly defined groups of patients; frequently only on patients with ischemic strokes in one brain region e.g. a. cerebri media (Branco et al., 2019).

The rehabilitation might also have been affected by particular members of the interprofessional staff, their experience, personal approach, possibilities, and willingness to share information within the whole team. The collaboration with the family is also very important and family members are often said to belong to the most important members of the rehabilitation team (Powers et al., 2018). When the patients are far from their home, the improvement can be worse.

The large differences in the economic results between three healthcare providers participating in the study that proved to be independent on patient categories might be caused, among others, by maintaining the providers'specific processes as the study was designed as a pragmatic one. Other reasons may include the established, partly differing practice of the evaluation tools used, no special selection of the patients for early rehabilitation, different practices in referring the patients from neurological departments to (early) rehabilitation wards, differences in the staffing of the providers (both in the numbers and their specialization). All these factors may require future examination, as it is hard to estimate the contribution of these phenomena to cost differences.

There are some limitations to the study that might affect the results. First, there is the limited time period (one year) and research capacity. The main limitations are the relatively small samples from the individual hospitals, the diversity of patients (different types of strokes, different localisations of stroke) and a missing control sample. Finally, it would be desirable to have some outcomes, both objective scores and subjective quality of life evaluation, in a medium-term perspective (limited results of a 12-month follow-up are presented in another paper). There were also limited possibilities of a statistical analysis due to small samples in some groups and no patients of category-1 in VFN and of category-4 in MNUL.

\section{Conclusions}

The analysis showed differences in patient management, length of stay, as well as in the costs and clinical outcomes between the involved hospitals and the categories of patients. However, the research showed an improvement in clinical 
outcomes after early rehabilitation in all stroke patient categories and hospitals. The differences in the costs of the hospitalization were caused mainly by hospitalization length. The differences in the average one-day costs were caused only by a particular hospital's treatment procedures and operational processes. Future research is desirable to investigate the possible gains in the efficiency and potential standardization of rehabilitation procedures in more detail.

\section{Funding}

The research leading to this paper was supported by the grant No. 410004194 provided by the General Health Insurance Company of the Czech Republic from their Secondary Prevention Fund.

\section{Conflict of interests}

The authors have no conflict of interests to declare.

\section{Včasná rehabilitace po cévní mozkové příhodě v centrech vysoce specializované cerebrovaskulární péče v České republice: srovnání tři iktových center}

\section{Souhrn}

Kvalita života pacientů a náklady spojené s léčbou následků cévních mozkových příhod jsou jednou z důležitých otázek českého zdravotnictví. Včasná rehabilitace osob po cévní mozkové příhodě má významný potenciál pro zlepšení kvality života pacientů a může přispět i k úspoře dlouhodobých společenských nákladů, které s tímto onemocněním a jeho následky souvisí. Ve třech iktových centrech v ČR byla provedena pragmatická longitudinální studie, která se zaměřila na nákladovou analýzu včasné rehabilitace po prodělání cévní mozkové příhody. Do studie bylo zahrnuto celkem 87 pacientů (29 z Prahy, 31 z Ústí nad Labem a 27 z Ostravy). Všem pacientům zařazeným do studie byla poskytnuta včasná rehabilitace nejpozději 70 dní po prodělání cévní mozkové př́ihody. Sběr dat probíhal souběžně se standardní péčí o pacienty na principu zdola nahoru. Rozdíly mezi jednotlivými poskytovateli spočívaly především v závažnosti stavu pacientů při přeložení z neurologických oddělení na lůžka včasné rehabilitace, délce hospitalizace, průměrných nákladech na hospitalizaci a do určité míry také na výsledcích rehabilitace (měřených pomocí skóre FIM). Analýza dat ukázala zlepšení klinických výsledků u všech skupin pacientů ve všech nemocnicích. Rozdíly $\mathrm{v}$ hospitalizačních nákladech byly způsobeny zejména rozdílnou délkou hospitalizace. Rozdíly v průměrných denních nákladech byly způsobeny výhradně léčebnými postupy a provozními zvyklostmi v jednotlivých nemocnicích.

Klíčová slova: cévní mozková příhoda; CMP; Česká republika; rozdíly mezi zdravotnickými zařízeními; včasná rehabilitace

\section{References}

1. Angerova Y, Marsalek P, Chmelova I, Gueye T, Uherek S, Briza J, et al. (2020). Cost and cost-effectiveness of early inpatient rehabilitation after stroke varies with initial disability: the Czech Republic perspective. Int J Rehabil Res 43(4): 376-382. DOI: 10.1097/mrr.0000000000000440.

2. Angerova Y, Svestkova O, Marsalek P, Chmelova I, Gueye T, Bartak M, et al. (2021). Cost analysis of early rehabilitation of patients after stroke in comprehensive cerebrovascular centers in the Czech Republic. Cent Eur J Public Health 29(2): 153-158. DOI: 10.21101/cejph.a6111.

3. Bernhardt J, Langhorne P, Lindley RI, Thrift AG, Ellery F, Collier J, et al. (2015). Efficacy and safety of very early mobilisation within $24 \mathrm{~h}$ of stroke onset (AVERT): a randomised controlled trial. Lancet 386(9988): 46-55. DOI: 10.1016/s01406736(15)60690-0.

4. Branco JP, Oliveira S, Sargento-Freitas J, Lains J, Pinheiro J (2019). Assessing functional recovery in the first six months after acute ischemic stroke: a prospective, observational study. Eur J of Phys Rehabil Med 55(1): 1-7. DOI: 10.23736/s19739087.18.05161-4.

5. Enderby P, Pandyan A, Bowen A, Hearnden D, Ashburn A, Conroy P (2017). Accessing rehabilitation after stroke a guessing game? Disabil Rehabil 39(7): 709-713. DOI: 10.3109/09638288.2016.1160448.

6. Hamann GF, Müller R, Alber B, Widder B (2016). Treatment in acute stroke - Stroke unit is mandatory. Neurol Psychiatry Brain Res 22(2): 105-109. DOI: 10.1016/j.npbr.2015.12.064.

7. Hsieh CY, Huang HC, Wu DP, Li CY, Chiu MJ, Sung SF (2018). Effect of Rehabilitation Intensity on Mortality Risk After Stroke. Arch Phys Med Rehabil 99(6): 1042-1048. DOI: 10.1016/j.apmr.2017.10.011.

8. Langhorne P, Wu O, Rodgers H, Ashburn A, Bernhardt J (2017). A Very Early Rehabilitation Trial after stroke (AVERT): a Phase III, multicentre, randomised controlled trial. Health Technol Assess 21(54): 1-120. DOI: 10.3310/hta21540.

9. Ministry of Health of the Czech Republic (2015). Seznam center vysoce specializované péče o pacienty s iktem [List of highly specialized centers for the care of patients after acute stroke]. Věstník MZ ČR, No. 11/2015: 52-56.

10. Powers WJ, Rabinstein AA, Ackerson T, Adeoye OM, Bambakidis NC, Becker K, et al. (2018). 2018 Guidelines for the Early Management of Patients With Acute Ischemic Stroke: A Guideline for Healthcare Professionals From the American Heart Association/American Stroke Association. Stroke 49(3): e46-e110. DOI: 10.1161/STR.0000000000000158.

11. Reddy KS (2016). Global Burden of Disease Study 2015 provides GPS for global health 2030. Lancet 388(10053): 1448-1449. DOI: 10.1016/s0140-6736(16)31743-3.

12. Škoda O, Herzig R, Mikulík R, Neumann J, Václavík D, Bar M, et al. (2016). Klinický standard pro diagnostiku a léčbu pacientů $\mathrm{s}$ ischemickou cévní mozkovou př́hodou a s tranzitorní ischemickou atakou - verze 2016 [Clinical Guideline for the Diagnostics and Treatment of Patients with Ischemic Stroke and Transitory Ischemic Attack - Version 2016]. Česká a slovenská neurologie a neurochirurgie 79(3): 351-363. DOI: 10.14735/ amcsnn2016351.

13. Stevens E, Emmett E, Wang Y, McKevitt C, Wolfe CD (2020). The burden of stroke in Europe. Brussels: Stroke Alliance for Europe.

14. Wafa HA, Wolfe CDA, Emmett E, Roth GA, Johnson CO, Wang YZ (2020). Burden of Stroke in Europe - Thirty-Year Projections of Incidence, Prevalence, Deaths, and DisabilityAdjusted Life Years. Stroke 51(8): 2418-2427. DOI: 10.1161/ strokeaha.120.029606.

15. Wilkins E, Wilson L, Wickramasinghe K, Bhatnagar P, Leal J, Luengo-Fernandez R, et al. (2017). European Cardiovascular Disease Statistics 2017. Brussels: European Heart Network. 